\title{
MENINGKATKAN PRESTASI BELAJAR ILMU PENGETAHUAN ALAM MELALUI METODE EKSPERIMEN PADA KELAS VIII B SMP NEGERI 2 JATIPURNO TAHUN PELAJARAN 2010/2011 (UPAYA PEMBELAJARAN AKTIF, INOVATIF, KREATIF, EFEKTIF, MENYENANGKAN)
}

\author{
Slamet Riyadi ${ }^{1}$ dan Joko Widiyanto ${ }^{2}$ \\ ${ }^{1}$ SMP Negeri 2 Jatipurno Wonogiri Jawa Tengah, ${ }^{2}$ Prodi Biologi IKIP PGRI Madiun \\ e-mail : riyadislamet01@gmail.com, joko_widiyanto@ymail.com
}

\begin{abstract}
ABSTRAK
Tujuan penelitian tindakan kelas ini adalah untuk meningkatkan prestasi belajar Ilmu Pengetahuan Alam melalui metode ekpserimen baik dari segi penguasan materi pelajaran maupun motivasi belajar. Penelitian ini dilakasanakan di SMP Negeri 2 Jatipurno kabupaten Wonogiri mulai tanggal 5 Desember 2010 sampai dengan 20 Maret 2011 pada kelas VIII B dengan jumlah peserta didik 32 terdiri dari 18 laki-laki dan 14 perempuan. Metode yang digunakan adalah eksperimen yaitu dengan melakukan pengujian terhadap pewarna maknan (siklus 1), efek bahan pemutih terhadap lingkungan air (siklus 2), dan pengawet bakso yang menggunakan boraks (siklus 3). Berdasarkan hasil penelitian bahwa penggunaan metode eksperimen dapat memberikan kontribusi yang positif terhadap peningkatan prestasi belajar siswa, peran aktif siswa, prestasi belajar siswa secara signifikan disamping itu juga menumbuhkan rasa keingintahuan dan sikap kritis terhadap permasalahan kehidupan sehari-hari yang terjadi, serta dapat mempengaruhi terhadap perbaikan kinerja guru dalam pembelajaran.
\end{abstract}

Kata Kunci : Eksperimen, Pretasi Belajar

\section{PENDAHULUAN}

Salah satu tujuan pembelajaran IPA adalah agar peserta didik memiliki kemampuan mengembangkan rasa ingin tahu, sikap positif, dan kesadaran terhadap adanya hubungan yang saling mempengaruhi antara Ilmu Pengetahuan Alam, lingkungan, teknologi dan masyarakat. Disamping itu peserta didik juga harus memiliki kemampuan melakukan inquiri untuk menumbuhkan kemampuan berfikir, bersikap, dan bertindak ilmiah serta berkomunikasi. Pernahkah kita berfikir bahwa pada saat kita mencuci, menggosok gigi, mandi, menggoreng makanan, mengkonsumsi makanan baik yang dibuat sendiri maupun dalam kemasan, sebenarnya kita telah berinteraksi dengan zat kimia. Jadi peran ilmu kimia dalam menghasilkan bahan-bahan makanan dan bahan untuk keperluan kehidupana manusia sangat besar.

Pelaksanaan pembelajaran IPA di SMP Negeri 2 Jatipurno, kurang efektif dan efesien hal ini tercermin dari penguasaan materi pelajaran oleh siswa tidak bisa bertahan lama, dimana sebagian besar yaitu $66 \%$ peserta didik belum bisa memahami kompetensi dasar IPA dengan baik sehingga belum dapat mencapai batas kriteria ketuntasan minimal yang ditetapkan yaitu 70. Kurangnya pemahaman siswa terhadap suatu kompetensi dasar adalah guru kurang menerapkan variasi metode pembelajaran, siswa kurang dilibatkan secara aktif dalam proses pembelajaran, keterbatasan sarana pembelajaran, motivasi belajar dan kemampuan siswa rendah, siswa beranggapan mata pelajaran IPA merupakan sesuatu yang sulit dan kurang bermanfaat. 
Setelah dilakukan observasi dan wanancara dengan siswa, kemudian dilanjutkan sharing ide dengan observer, serta melihat hasil ulangan harian dan ulangan akhir semester pada kelas VIII B, maka sebagai faktor utama yang diprediksikan sebagai penyebab rendahnya prestasi belajar siswa terhadap suatu kompetensi dasar IPA adalah guru belum menerapkan metode pembelajaran yang variatif dan menarik serta kurang melibatkan aktivitas maupun tanggung jawab siswa baik secara individual maupun kelompok dalam kegiatan pemebelajaran.

Jika permasalahan tersebut tidak segera diatasi, berbagai resiko dalam proses pembelajaran IPA adalah (1) siswa akan semakin menjauhi dan malas belajar Ilmu Pengetahuan Alam, (2) siswa semakin kesulitan dalam memahami kompetensi dasar yang harus dikuasi, (3) guru mengalami kesulitan dalam menstranfer pengetahuan kepada siswa, (4) proses PBM menjadi terhambat, (5) prestasi siswa menjadi semakin terpuruk dan sulit untuk ditingkatkan.

Memperhatikan realita diatas, maka perlu adanya usaha untuk meningkatkan penguasan kompetensi dasar IPA dengan melakukan tindakan kelas yaitu dengan melaksankan pembelajaran yang adaptif, kreatif, inovtif, meyenangkan dan bermakna, serta melibatkan peran aktif siswa, dan meningkatkan tanggung jawab siswa baik secara individual atau kelompok. Dengan menggunakan metode ekperimen merupakan tindakan pemecahan masalah yang diterapakan dalam upaya meningkatkan pemahaman kompentensi dasar IPA. Disamping itu siswa mengetahui manfaat pembelajaran IPA, dengan harapan dapat meningkatkan prestasi belajar IPA pada kelas VIII B SMP Negeri 2 Jatipurno kabupaten Wonogiri tahun pelajaran 2010/2011.

\section{METODE PENELITIAN}

Metode yang digunakan dalam penelitian ini adalah Penelitian tindakan kelas yang dilaksanakan di SMP Negeri 2 Jatipurno kabupaten Wonogiri propinsi Jawa Tengah kelas VIII B tahun pelajaran 2010/2011. Pemilihan tempat penelitian tindakan kelas ini didasarkan bahwa kelas VIII B sebagai kelas yang mempunyai permasalahan pembelajaran yang memerlukan penanganan serius dan mendesak sekaligus pada kelas ini peneliti melaksanakan tugas pembelajaran.

1. Teknik dan Alat pengumpulan data.

Dari hasil kegiatan penelitian tindakan kelas ini diperoleh beberapa data, antara lain :

Tabel 1. Hasil penilaian proses dari eksperimen pada siklus 1 sampai 3 dengan rubrik / pedoman penskoran

\begin{tabular}{clc}
\hline No & Aspek yang dinilai & Skor \\
1 & Menyiapkan alat da bahan dengan benar & 10 \\
\hline 2 & Bekerjasama dengan baik dalam kelompok & 10 \\
\hline 3 & Melakukan kegiatan sesuai dengan prosedur yang benar & 30 \\
\hline 4 & Memperoleh data dari percobaan dengan baik & 15 \\
\hline 5 & Membuat kesimpulan dengan benar & 15 \\
\hline 6 & Presentasi hasil kegiatan & 20 \\
\hline & Jumlah skor & 100 \\
\hline
\end{tabular}

a. Hasil bejar siswa yaitu tes awal (pretes) dilaksanakan sebelum kegiatan dimulai dan hasil ulangan harian. b. Observasi untuk mengetahui peran aktif siswa dalam proses pembelajaran

c. Learning Logs Siswa untuk mengetaui kemajuan belajar siswa. 
2. Validasi Data

Agar memperoleh data yang valid maka diperlukan validasi data. Untuk memvalidasi data yang diperoleh melalui penllaian proses dengan menggunakan skor penilaian 6 aspek dan terlebih dahulu dibuat skor penilaian. Untuk soal tes awal dan akhir setiap siklus dibuat kisi-kisi dengan maksud agar soal yang dibuat tidak mengelompok pada satu bahasan tertentu tetapi menyebar keseluruh pokok bahasan, jugar adanya penyebaran pada tingkat kesulitan soal. Agar proses hasil belajar lebih valid lagi maka diperlukan trianggulasi sumber yang dalam penelitian tindkan kelas ini lebih popular dengan istilah kolaborasi.

3. Analisis Data

Hasil belajar siswa dianalisis dengan diskriptif komparatif yaitu membandingkan nilai data kondisi awal dibandingkan dengan nilai data siklus pertama maupun nilai data siklus kedua. Data proses belajar juga dibandingkan nilai kondisi awal dengan hasil siklus 1 dan 2, termasuk hasil observasi dan leaninglogs siswa kemudian membandingkan hasil kegiatan antar siklus dan ditindaklanjuti dengan refleksi.

4. Prosedur Penelitian

Kegiatan penelitian tindakan kelas ini direncanakan 3 siklus. Penelitian ini diawali kegiatan observasi sebagai penjajagan untuk memperoleh informasi awal dan gambaran terhadap permasalahan yang sedang dihadapi, kemudian diteliti, tindakan yang telah dilakukan oleh guru dan dilanjutkan dengan membahas hasil observasi serta merencanakan dan menetapkan tindakan yang diperlukan.

Rencana penelitian ini menggunakan model proses yang berkesinambungan, mulai dari proses penelitian tindakan siklus 1, ditindaklanjuti proses penelitian tindakan pada siklus 2 dan ditindaklanjuti proses penelitian pada siklus 3 .

Prosedur penelitian tindakan kelas ini setiap siklus meliputi : a) Perencanaan / persiapan (planning), b) Pelaksanaan tindakan (acting), c) Observasi (observasion) dan evaluasi hasil pemantauan, d) Refleksi (reflecting)

\section{HASIL PENELITIAN}

1. Hasil Kegiatan Penilaian Proses Tiap Siklus a. Siklus 1

Pada pelaksanaan siklus 1 selama dua pertemuaan siswa melakukan proses pembelajaran dengan baik, rasa percaya dirinya mulai tumbuh, sikap toleransi dan kerjasama mulai tumbuh, dalam melakukan presentasi masih kurang percaya diri, sehingga diperoleh nilai dalam proses pembelajaran sebagaimana dapat dilihit pada foto, tabel dan grafik penilaian siklus 1 :

Tabel 2. Hasil Penilaian pada eksperimen siklus 1

\begin{tabular}{ccccc} 
No & Rentang Nilai & Jumlah & Persentase & Kterangan \\
\hline 1 & $<60$ & 2 & $5 \%$ & Belum Tuntas \\
\hline 2 & $60-69$ & 9 & $22,5 \%$ & Belum Tuntas \\
\hline 3 & $70-79$ & 27 & $67,5 \%$ & Tuntas \\
\hline 4 & $80-89$ & 2 & $5 \%$ & Tuntas \\
\hline 5 & $90-100$ & 0 & $0 \%$ & Tuntas \\
\hline & Jumlah & 40 & $77,5 \%$ & Belum Tuntas Klasikal \\
\hline
\end{tabular}

Dari tabel, di atas dapat dibaca bahwa pada silus 1 Siswa yang belum tuntas adalah 11 siswa atau $27,5 \%$, siswa yang sudah tuntas adalah 72,5\% dengan rata-rata nilai 71,49 ini berarti secara klasikal belum tuntas. Hal ini disebabkan siswa ketika mengambil alat dan 
bahan masih mengalami kendala, kerja sama kelompok yang kurang kompak sehingga waktu yang diperlukan untuk menyesaikan tugas terlalu lama, ketika presentasi masih kurang percaya diri. Dari permasalahan ini maka perlu diadakan evaluasi dan penguatan sehingga pada siklus kedua nanti ada perbaikan dimasing-masing kelompok. Pada siklus 2 nanti urutan kerjanya sama tetapi kegiatan eksperimennya dampak negative bahan pemutih terhadap kehidupan ikan (hewan air) hal ini bertujuan untuk menumbuhkan rasa ingin tahu dan cara berpikir kritis terhadap permasalahan di sekitarnya dalam kehidupan sehari-hari.

b. Siklus 2

Berdasarkan hasil refleksi antara peneliti dan guru kolaborator pada siklus 1, maka pada siklus 2 siswa diingatkan akan kekurangan dan kelamahan pada siklus 1 untuk diperbaiki dan tidak diulang kembali. Kegiatan yang dilakukan pada siklus 2 adalah melakukan eksperimen dampak negative pemutih terhadap kehidupan air (ikan) hal ini bertujuan untuk menumbuhkan rasa ingin tahu dan cara berpikir kritis terhadap permasalahan di sekitarnya yang terjadi dalam kehidupan sehari-hari. Pada pelaksanaan siklus 2 selama satu pertemuaan siswa melakukan proses pembelajaran dengan baik, rasa percaya dirinya berkembang dengan baik, sikap toleransi dan kerjasama berkembang dengan baik, dalam presentasi sudah ada perkembangan kearah percaya diri, hal dapat dilihit pada tabel berikut

Tabel 3. Hasil Penilaian pada eksperimen siklus 2

\begin{tabular}{ccccc}
\hline No & Rentang Nilai & Jumlah & Persentase & Kterangan \\
\hline 1 & $<60$ & 0 & $0 \%$ & Belum Tuntas \\
\hline 2 & $60-69$ & 3 & $7,5 \%$ & Belum Tuntas \\
\hline 3 & $70-79$ & 10 & $25 \%$ & Tuntas \\
\hline 4 & $80-89$ & 27 & $67,5 \%$ & Tuntas \\
\hline 5 & $90-100$ & 0 & $0 \%$ & Tuntas \\
\hline & Jumlah & 40 & & Tuntas Klasikal
\end{tabular}

Dari tabel, di atas dapat dibaca bahwa pada silus 2 Siswa yang belum tuntas adalah 3 siswa atau 7,5 \%, siswa yang sudah tuntas adalah 39 atau 92,5 \% dengan rata-rata kelas 80,31 ini berarti secara klasikal sudah tuntas. Hal ini disebabkan siswa ketika mengambil alat dan bahan sudah tidak ada kendala, kerja sama kelompok kompak sehingga waktu yang diperlukan untuk menyelesaikan tugas tepat waktu, ketika presentasi sudah mulai tumbuh percaya dirinya. Perasalahan yang muncul adalah siswa menghendaki pada siklus 3 melakukan eksperimen menguji bakso yang menggunakan bahan pengawet boraks, hal ini bertujuan untuk menumbuhkan rasa ingin tahu dan cara berpikir kritis terhadap permasalahan di sekitarnya yang terjadi dalam kehidupan sehari-hari. Dari permasalahan ini maka setelah diadakan evaluasi dan sharing ideal antara peneliti, kolaborator dan siswa yang di tunjuk, kemudian siswa diberi penguatan sehingga pada siklus ketiga nanti dapat bekerja lebih baik lagi. Dimana pada siklus 3 nanti dengan urutan kerja yang telah ditetapkan dalam rencana kegiatan, bahan yang diuji (bakso), siswa diberi kebebasan untuk mencari sendiri di daerah sekitarnya hal ini bertujuan untuk menumbuhkan rasa ingin tahu dan cara berpikir kritis terhadap permasalahan di sekitarnya dalam kehidupan sehari-hari. 
c. Siklus 3

Berdasarkan hasil refleksi antara peneliti dan guru kolaborator pada siklus 2, maka pada siklus 3 siswa diingatkan akan kekurangan dan kelamahan pada siklus 2 untuk diperbaiki dan tidak diulang kembali. Kegiatan yang dilakukan pada siklus 3 adalah melakukan eksperimen pemakaian bahan pengawet borak pada makanan bakso hal ini bertujuan untuk menumbuhkan rasa ingin tahu dan cara berpikir kritis terhadap permasalahan di sekitarnya yang terjadi dalam kehidupan sehari-hari.

Pada pelaksanaan siklus 3 selama satu pertemuaan siswa melakukan proses pembelajaran dengan baik, rasa percaya dirinya berkembang dengan baik, sikap toleransi dan kerjasama berkembang dengan baik, dalam presentasi sudah percaya diri, hal dapat dilihat pada tabel berikut:

Tabel 4. Hasil Penilaian pada eksperimen siklus 3

\begin{tabular}{ccccc}
\hline No & Rentang Nilai & Jumlah & Persentase & Keterangan \\
\hline 1 & $<60$ & 0 & $0 \%$ & Belum Tuntas \\
\hline 2 & $60-69$ & 2 & $5 \%$ & Belum Tuntas \\
\hline 3 & $70-79$ & 2 & $5 \%$ & Tuntas \\
\hline 4 & $80-89$ & 31 & $77,5 \%$ & Tuntas \\
\hline 5 & $90-100$ & 5 & $12,5 \%$ & Tuntas \\
\hline Jumlah & & 40 & & Tuntas Klasikal \\
\hline
\end{tabular}

Dari tabel di atas dapat dibaca bahwa pada siklus 3, siswa yang belum tuntas adalah 1 siswa atau $5 \%$, siswa yang sudah tuntas adalah 29 atau $95 \%$ dengan rata-rata nilai 84, 48 ini berarti secara klasikal sudah tuntas. Hal ini disebabkan siswa ketika mempersiapkan alat dan bahan sudah tidak ada kendala, sudah kompak dalam bekerja sehingga waktu yang diperlukan untuk menyesaikan tugas tepat waktu, ketika presentasi sudah percaya diri. Dari kenyataan ini, maka setelah diadakan evaluasi dan sharing ideal antara peneliti, kolaborator, dan siswa kelas IX yang ditunjuk, kemudian siswa diberi penguatan dan dinyatakan siswa sudah bekerja sesuai dengan yang diharapkan, maka siklus ke 4 tidak perlu untuk dilaksanakan.

\section{Prestasi Belajar Siswa}

Unatuk mengetahui perkembangan prestasi belajar siswa mulai dari sebelum dilakukan tindakan sampai setelah dilakukan tindakan.

Tabel 5. Hasil Belajar Siswa pretes, ulangan harian, siklus 1 s.d 3

\begin{tabular}{|c|c|c|c|c|c|c|c|}
\hline \multirow[t]{2}{*}{ No } & \multirow{2}{*}{$\begin{array}{c}\text { Rentang } \\
\text { Nilai }\end{array}$} & \multicolumn{2}{|c|}{ TES } & \multicolumn{3}{|c|}{ Tindakan } & \multirow[t]{2}{*}{ Ket } \\
\hline & & Awal & Ul. Harian & Siklus 1 & Siklus 2 & Siklus 3 & \\
\hline 1 & $<60$ & 3 & 0 & 2 & 0 & 0 & TT \\
\hline 2 & $60-69$ & 24 & 4 & 9 & 3 & 2 & TT \\
\hline 3 & $70-79$ & 8 & 4 & 29 & 10 & 2 & $\mathrm{~T}$ \\
\hline 4 & $80-89$ & 5 & 22 & 2 & 27 & 31 & $\mathrm{~T}$ \\
\hline 5 & $90-100$ & 0 & 10 & 0 & 0 & 5 & $\mathrm{~T}$ \\
\hline \multicolumn{2}{|c|}{ Jumlah } & 40 & 40 & 40 & 40 & 40 & \\
\hline
\end{tabular}

Berdasarkan table diatas dapat dianalisa bahwa hasil tindakan di setiap siklus, tentang kemajuan prestasi belajar siswa. Pada saat diadakan penjajagan (pre tes pada awal siklus) 
dari 40 siswa : 27 siswa belum tuntas dan 13 siswa yang tuntas. Pada siklus 1 dari 40 siswa : 11 siswa belum tuntas dan 29 siswa sudah tuntas. Pada siklus 2 dari 40 siswa : 3 siswa belum tuntas, 37 siswa sudah tuntas. Pada siklus 3 dari 40 siswa : 2 siswa belum tuntas dan 38 sudah tuntas. Pada ulangan harian dari 40 siswa : 4 siswa belum tuntas dan 36 siswa sudah tuntas. Disamping itu peningkatan prestasi belajar siswa juga ditunjukan oleh peningkatan nilai rata - rata pada siklus 1 , siklus 2, siklus 3, termasuk ulangan harian.

3. Kondisi Pembelajaran

Pemantauan peningkatan kondisi pembelajaran dikelas dilakukan melalui wawancara dengan siswa, observasi oleh observer baik guru lain maupun siswa yang ditunjuk, menunjukan bahwa terjadi peningkatan prestasi belajar dari waktu kewaktu. Hal ini tampak pada gairah, semangat, peran serta dan kepedulian siswa serta tanggungjawab selama proses belajar mengajar berlangsung.

Suasana pembelajaran yang kondusif ini terlihat dengan munculnya minat belajar dan motivasi belajar siswa, penciptaan hubungan dan kerjasama antar personal, diskusi, presentasi, dan spontanitas dapat berkembang sehingga hambatan-hambatan komunikasi antara guru dan siswa dapat berkurang. Suasana yang kondusif menunang tercapainya iklim belajar yang lebih baik dilingkungan sekolah serta memberi motivasi pada rekan guru untuk lebih terbuka dan menerapkan pendekatan dan metode-metode pembelajaran yang lebih bervariasi.

Tabel 6. Kondisi Pembelajaran

\begin{tabular}{llrrrrr}
\hline \multirow{2}{*}{ NO } & \multirow{2}{*}{ Kondisi Pembelajaran } & \multicolumn{5}{c}{ Perkembangan } \\
\cline { 3 - 6 } & & Pra & Siklus 1 & Siklus 2 & Siklus 3 & UH \\
\hline 1 & Respon positif pada guru & $35 \%$ & $65 \%$ & $80 \%$ & $90 \%$ & $100 \%$ \\
\hline 2 & Partisispasi aktif siswa & $7,5 \%$ & $60 \%$ & $75 \%$ & $85 \%$ & $90 \%$ \\
\hline 3 & Prestasi belajar siswa & $15 \%$ & $55 \%$ & $75 \%$ & $90 \%$ & $95 \%$ \\
\hline 4 & Komunikasi siswa dalam pembelajaran & $10 \%$ & $45 \%$ & $60 \%$ & $75 \%$ & $80 \%$ \\
\hline 5 & Kepuasan dalam belajar & $20 \%$ & $60 \%$ & $75 \%$ & $85 \%$ & $90 \%$ \\
\hline 6 & Hubungan siswa dengan guru & $25 \%$ & $65 \%$ & $80 \%$ & $92,5 \%$ & $100 \%$ \\
\hline
\end{tabular}

4. Hasil Learning Logs Siswa

Learning logs siswa dipergunakan untuk mengungkapkan pendapat siswa tentang jalannya proses pembelajaran yang baru saja dilaksanakan, tingkat pemahaman materi pembelajaran dengan pendekatan yang baru saja dilaksanakan, kendala pembelajaran yang baru saja dirasakan oleh siswa dengan menggunakan metode eksperimen, keinginanan atau saran siswa dalam upaya peningkatan pemahaman dan penguasaan kompetensi Dasar sebaiknya menggunakan pendekatan apa dan metode apa yang tepat untuk dilaksanakan sesuai dengan harapan siswa. Angket ini diberikan kepada semua siswa setelah selesai mengikuti siklus, dengan harapan dapat memberikan informasi kepada peneliti guna perbaikan perencanaan siklus berikutnya. 
Tabel 7. Hasil Learning Log Siswa

\begin{tabular}{|c|c|c|c|c|c|c|c|}
\hline No & Indikator & Respon & $\begin{array}{c}\text { Pra } \\
\text { Siklus }\end{array}$ & Siklus 1 & Siklus 2 & Siklus 3 & UH \\
\hline \multirow{3}{*}{1} & Pendapat siswa tentang & 1. Senang & $10 \%$ & $25 \%$ & $40 \%$ & $50 \%$ & $52 \%$ \\
\hline & kegiatan belajar yang baru & 2. Biasa & $30 \%$ & $35 \%$ & $40 \%$ & $40 \%$ & $43 \%$ \\
\hline & saja berlangsung & 3. Tidak & $60 \%$ & $40 \%$ & $20 \%$ & $10 \%$ & $5 \%$ \\
\hline \multirow{3}{*}{2} & Pemahaman kompetensi & 1. Mudah & $7,5 \%$ & $30 \%$ & $42,5 \%$ & $50 \%$ & $45 \%$ \\
\hline & yang baru saja berlangsung & 2. Biasa & $30 \%$ & $40 \%$ & $42,5 \%$ & $45 \%$ & $50 \%$ \\
\hline & & 3. Sulit & $47,5 \%$ & $30 \%$ & $15 \%$ & $5 \%$ & $5 \%$ \\
\hline \multirow{3}{*}{3} & Perbandingan PBM & 1. Variasi & $15 \%$ & $40 \%$ & $42,5 \%$ & $70 \%$ & $75 \%$ \\
\hline & konvensional dengan PBM & 2. Biasa & $25 \%$ & $35 \%$ & $40 \%$ & $20 \%$ & $20 \%$ \\
\hline & dengan metode eksperimen & 3. Tidak & $75 \%$ & $25 \%$ & $17,5 \%$ & $10 \%$ & $5 \%$ \\
\hline \multirow{3}{*}{4} & Kendala pembelajaran & 1. ada & $10 \%$ & $30 \%$ & $15 \%$ & $10 \%$ & $10 \%$ \\
\hline & yang dialami siswa melalui & 2. biasa & $50 \%$ & $40 \%$ & $45 \%$ & $50 \%$ & $40 \%$ \\
\hline & Metode eksperimen & 3. tidak & $40 \%$ & $30 \%$ & $30 \%$ & $40 \%$ & $50 \%$ \\
\hline \multirow[b]{3}{*}{5} & Saran dalam upaya & 1. Variasi & $50 \%$ & $60 \%$ & $75 \%$ & $85 \%$ & $100 \%$ \\
\hline & meningkatkan pemahaman & 2. biasa & $30 \%$ & $35 \%$ & $25 \%$ & $15 \%$ & - \\
\hline & $\begin{array}{l}\text { kompetensi materi } \\
\text { pelajaran dengan variasi }\end{array}$ & 3. tidak & $20 \%$ & $5 \%$ & - & - & - \\
\hline
\end{tabular}

pendekatan pembelajaran

Hasil analisis learning logs siswa dan wawancara dengan siswa, dapat ditarik kesimpulan bahwa siswa merasa senang dengan metode pembelajaran ekperimen dengan alasan motivasi belajar meningkat, siswa merasa senang, belajar menjadi rileks, siswa dapat melakukan pengujian sendiri dengan alat dan peralatan yang sederhana, bahan yang murah, mudah di dapat serta mudah untuk dilakukan sehingga prestasi belajar siswa menjadi meningkat.

Dari kenyataan ini, maka setelah diadakan evaluasi dan sharing ide antara peneliti, kolaborator dan siswa kelas IX yang ditunjuk, dapat kami simpulkan bahwa metode eksperimen dapat meningkatkan prestasi belajar siswa kelas VIII B pada tahun pelajaran 2010/2011.

\section{PEMBAHASAN}

Dari hasil penelitian tindakan kelas mulai kegiatan persiapan, tindakan siklus 1 sampai dengan siklus 3 , berdasarkan data hasil pretes, ulangan harian, observasi, ulangan harian, dan dokumen foto kegiatan dapat kita pahami bahwa proses pembelajaran dengan menggunkan metode eksperimen terdapat beberapa faktor-faktor yang perlu diperhatikan dan dapat diperbaiki melalui proses pembelajaran yaitu:

1. Prestasi belajar siswa meningkat.

Berdasarkan hsil penelitian di atas dapat dianalisa bahwa hasil tindakan di setiap siklus, terjadi kemajuan prestasi belajar siswa. Pada saat diadakan penjajagan (pre tes pada awal siklus) dari 40 siswa: 27 siswa belum tuntas dan 13 siswa yang tuntas. Pada siklus 1 dari 40 siswa: 11 siswa belum tuntas dan 29 siswa sudah tuntas. Pada siklus 2 dari 40 siswa: 3 siswa belum tuntas, 37 siswa sudah tuntas. Pada siklus 3 dari 40 siswa: 2 siswa belum tuntas dan 38 sudah tuntas. Pada ulangan harian setelah KD 4.1 selesai dari 40 siswa: 4 siswa belum tuntas dan 36 siswa sudah tuntas, berarti ketuntasan klasikal mencapai $90 \%$, berdasarkan hasil tersebut maka dapat nayatakan secara klasikal sudah tuntas. Disamping itu peningkatan prestasi belajar siswa juga ditunjukan oleh peningkatan nilai rata - rata tiap-tiap yaitu siklus 1 , siklus 2, siklus 3, termasuk ulangan harian. Hal ini didukung oleh pendapat Syaiful Bahri Zamarah (2000: 62) mengungkapkan bahwa "metode 
eksperimen adalah metode pemberian kesempatan kepada anak didik perorangan atau kelompok, untuk dilatih melakukan suatu proses atau percobaan".

2. Peran akatif siswa dalam proses pembelajaran bertambah baik.

Partisipasi aktif siswa dalam kegiatan ekpserimen ini sangat tampak yaitu dari jumlah anggota kelompok 4-5 siswa pada siklus 1 dengan mengidentifikasi macammacam gerak pada tumbuhan, hal ini dimaksudkan untuk menumbuhkan keingingtahuan dan sikap kritis siswa terhadap terjadinya gerak pada tumbuhan karena rangsang sentuhan. Pada siklus 2 anggota 4-5 siswa menyelidiki efek negatif penggunaan bahan pemutih pada kesehatan lingkungan. Hal ini dimaksudkan untuk menumbuhkan keingingtahuan dan sikap kritis siswa terhadap efek negatif penggunaan bahan pemutih pada kesehtan lingkungan kususnya air. Pada siklus 3 anggota 4-5 siswa menyelidiki bahan pengawet pada bakso. Hal ini dimaksudkan untuk menumbuhkan keingingtahuan dan sikap kritis siswa terhadap efek negatif penggunaan bahan pengawet boraks pada bakso.Ternyata mulai siklus 1 sampai 3 siswa dapat melakuan eksperimen dengan baik dan lancar serta hasil yang diperoleh sangat memuaskan.

3. Sikap kritis terhadap permasalahan dalam

kehidupan sehari-hari meningkat.

Sikap kritis siswa mulai tampak setelah berakir siklus 1 yaitu siswa mengusulkan untuk kegiatan siklus 2 yaitu menguji efek negatif bahan pemutih terhadap lingkungan khususnya air, setelah kami diskusikan dengan observer usulan tersebut disetujui. Siswa yang diberi tugas untuk membawa dua ekor ikan yang ukurannya hampir sama dan bahan pemutih. Pada siklus ketiag siswa mengusulkan untuk menguji bakso yang menggunakan bahan pengawet boraks dengan ekstraks kunir, setelah kami diskusikan dengan observer usulan tersebut disetujui. Siswa diberi tugas untuk membawa membawa bakso yang mereka beli di sekitar tempat tinggal mereka untuk di uji. Selama pelaksanaan kegiatan eksperimen mulai siklus 1, 2 dan $382 \%$ melaksanakan dengan perasaan senang dan bangga.

4. Dampak yang terjadi dari penerapan metode pembelajaran eksperimen

Dampak yang terjadi dari penerapan metode pembelajaran eksperimen adalah dapat memberikan kontribusi yang positif dan menumbuhkan rasa puas pada siswa karena guru menyajikan proses pembelajaran yang betul-betul bermakna sehingga dapat meningkatkan prestasi belajar, peran aktif siswa, menumbuhkan rasa keingintahuan dan sikap kritis terhadap permasalahan kehidupan sehari-hari yang terjadi.

\section{KESIMPULAN}

Dari pelaksanaan kegiatan penelitian tindakan kelas diatas dapat ditarik kesimpulan bahwa prestasi belajar Ilmu Pengetahuan Alam pada kelas VIII B SMP Negeri 2 Jatipurno tahun pelajaran 2010/2011 dapat ditingkatkan melalui penggunaan metode eksperimen.

\section{DAFTAR PUSTAKA}

BNSP. 2007. Model Silabus dan Perencanaan Pembelajaran IPA. Jakarta: Depdiknas

Departemen Pendidikan Nasional. 2007. IPA SMP Kelas VIII. Jakarta

2005. Materi Pelatiahan Terintegrasi Ilmu Pengetahuan Alam- Kimia. Jakarta: Direktorat Pendidikan Lanjuta Pertama.

, 2005. Materi Pelatihan Terintregrasi Ilmu Pengetahuan Alam- Biologi. Jakarta: Direktorat Pendidikan lanjutan Pertama.

Faller, Klingmüller, dan Timmer. 2003. Simulation Methods for Optimal 
Experimental Design in Systems Biology, The Society for Modeling and Simulation International. 79 (12): 717 725

Istamar Syamsuri, dkk. 2007. IPA Biologi untuk SMP kelas VIII. Jakarta: Erlangga

Maksun, 2008. Upaya Meningktkan Prestasi Belajar IPA Melalui Metode Eksperimen pada kelas VIII C SMP Negeri 2 Kendal tahun pelajaran 2008/2009.

Michael Komorek; Reinders Duit. 2004. The teaching experiment as a powerful method to develop and evaluate teaching and learning sequences in the domain of non-linear systems. International Journal of Science Education 26 (5): 619-633.

Muhibbin Syah. 1995. Psikologi Pendidikan dengan Pendekatan Baru. Bandung: Remaja Rosdakarya

Nana Sudjana. 1998. Dasar-dasar Proses Belajar. Bandung: Sinar Baru

Oemar Hamalik, 1990, Psikologi Belajar dan Mengajar, Bandung, Sinar Baru
Perry Burhan. 2007. Prospek Pengembangan Materi Pendidikan Kimia Masa Depan. Makalah keynote speaker pada International Conference on science education: Bandung

Joko Priyanto, 2008.Upaya Meningkatkan Pemahaman Konsep IPA Melalui Metode Eksperimen Pada siswa Kelas VIII A SMP Negeri 1 Wonosari Semester I Tahun Pelajaran 2010/2011

Surso AY, Anna Permanasari, Kardiawarman. 2003. Ensiklopedi Sains dan Kehidupan. Jakarta: Triaty Samudra Berlian.

Ricard. Jack C and Theodore S. 1996. Appoach and Methode in Language Teaching. Cambridge Unevercity Press.

Wahyu Hidayati. 2009. Upaya Meningktkan Prestasi Belajar Biologi Pada Materi Sistem Pencernaan makanan Manusia Melalui Praktikum di Kelas VIII A SMP Negeri 1 Slogohimo Tahun pelajaran 2008/2009. 